\title{
Christian Wehr
}

Meditación espirituale imaginación poética: Estudios sobre Ignacio de Loyolay

Francisco de Quevedo. Translated by Elvira Gómez Hernández. Madrid:

Iberoamericana / Vervuert, 2017. Pp. 348. €29.80.

Meditación espiritual e imaginación poética: Estudios sobre Ignacio de Loyola $y$ Francisco de Quevedo by Christian Wehr is a masterful analysis of Francisco de Quevedo's poetry for the ways in which it weaves together the main literary currents and spiritual practices of seventeenth-century Spain. On the one hand, it highlights the prominence that was given to engaño (deception) in Spanish literature of the Golden Age, while on the other hand it connects this literary theme to the method of contemplation as it is spelled out in the Spiritual Exercises of St. Ignatius of Loyola.

Quevedo is now remembered as one of the more prominent poets and intellectuals of the Spanish Golden Age. As a student of the Imperial College in Madrid during the late sixteenth century, he would have been widely exposed in his youth to the pedagogical, catechetical, and spiritual techniques that the Jesuits employed in the classroom and the pulpit. This exposure and the influence Jesuit ideals had on Quevedo has long merited the attention Wehr gives them in his book. Perhaps Wehr's greatest strength is in his treatment of engaño within the context of humanistic thought in Counter Reformation Spain. In Wehr's conclusion, the link between the Ignatian Spiritual Exercises and Quevedo's poetry resides in a clearer understanding of how engaño came to be prominent as a literary theme in the early modern period.

Meditación espiritual e imaginación poética is divided into five sections. The first ("Meditación y poesía") serves as the book's introduction by defining engaño not only as an "omnipresent" cultural aesthetic of the European, and more so of the Spanish baroque, but also how the Ignatian Spiritual Exercises came to emerge in their "orienting function" as a way to negotiate a culture of paradox (13-14). According to Wehr, the Exercises "estructuran la relación que tiene consigo mismo el sujeto-a quien su propia interioridad se le ha vuelta opaca-, pero también organizan la problemática relación con el mundo exterior del engaño" (provide a framework in which the practitioner may relate to the self-whose own interiority has become more transparent—but they also help put into perspective the problematic relationship one has with exterior world of engaño) (14).

In section two ("Texto y contexto de los Ejercicios ignacianos") Wehr performs what he considers an archeological dig around the phenomenon or emergence of engaño as a defining component of baroque culture, "una arqueología del engaño barroco" (an archeology of the baroque engaño) (19), by 
connecting it to the cosmological and metaphysical shifts that took place in early modern Europe, precisely when Loyola would begin to develop his own spiritual technique of contemplation in the Exercises. Here, the Spanish Jesuit writer Baltasar Gracián receives prominent attention for the conceptista style that came to be characteristic of his secular texts in the seventeenth century. Wehr then goes on to describe the "innovative potential" the Exercises brought to a culture defined by deceptiveness by signaling their more definitive components, such as the "discernment spirits" and the "election" (95, 98): "La toma de decisión activa se sustituye por el recibimiento pasivo de una señal divina que hay que descifrar" (The active making of a decision is substituted by the passive reception of a divine sign that must be deciphered) (98).

Section three ("Ciclo poético ignaciano: Un Heráclito cristiano") begins with a look at Quevedo's famous ascetical treatise, La cuna y la sepultura (The cradle and the grave), by identifying the relationship it has to both the Spiritual Exercises and the Spiritual Diary of Loyola. On the one hand, Wehr connects Quevedo to the spiritual asceticism of the Ignatian texts-namely that of abandoning one's will in favor of doing that of God's-and, on the other hand, shows how elements of Ignatian teaching were carried into seventeenthcentury poetics by Quevedo and other prominent writers of the time, such as Félix Lope de Vega. Not losing sight of engaño in deciphering God's will, Wehr then explains in greater detail how the poetic cycle of Quevedo's Heráclito cristiano (Christian Heraclitus) relates to the techniques of Ignatian imagination and the preceding tradition that Ignatius drew from in the imitatio Christi: "Ya a partir de la mitad del siglo XVI se crean la condiciones externas para que se asimilen las técnicas espirituales de representación e imaginación a través de nuevos contextos mundanos y literarios" (From the middle of the sixteenth century external conditions began to make it possible to assimilate spiritual techniques of representation and imagination within the new literary and social contexts) (239).

In section four ("Amor petrarquista y mortificación meditativa: Canta sola a Lisi como ciclo dialógico") Wehr's analysis concentrates on the influence of Petrarchan poetry in Quevedo's anthology Canta sólo a Lisi (Poems to Lisi), and includes an exposition on Quevedo's incorporation of Ignatian imagination into these same poems. Just as he does in section three, Wehr situates Quevedo's poetry within the overarching context of engaño in the Spanish baroque, but in doing so points out the nuances that differentiate the two poetic cycles: "Mientras que, en el Heráclito cristiano, los procedimientos de la autoafirmación espiritual llevan a superar una inicial situación de tentación y de engaño, en Canta sola a Lisi ese proyecto da un vuelco a lo contrario después de un comienzo semejante" (While in Christian Heraclitus the processes of 
spiritual self affirmation overcome the initial experience of temptation and deception, in Poems to Lisi that project has a similar beginning but then takes an opposite turn) (310).

Section five ("Aberturas: meditación-doctrina de Estado-sátira") draws the reader's attention to the presence of the Ignatian spiritual tradition in other works of Quevedo, such as Los sueños (The dreams) and Política de Dios (The politics of God). Wehr concludes not only by showing how Quevedo drew from the Ignatian sources and incorporated them in both his poetry and his treatises, but by clearly establishing "la gran importancia que tuvieron los Ejercicios [...] como instrumento de autoformación" (the great importance the Spiritual Exercises had [...] as an instrument in the formation of self understanding) in the Spanish Golden Age (321).

Meditación espiritual e imaginación poética is well researched and edited, and translated well from the original German (Geistliche Meditation und poetische Imagination: Studien zu Ignacio de Loyola und Francisco de Quevedo) into Spanish by Gómez Hernández, and is a welcome addition to the abundant scholarly production on Quevedo. Its focus on the Ignatian Spiritual Exercises offers a new and more in-depth approach to ways in which the spiritual currents of the Spanish Counter Reformation came to influence literary creation in Quevedo's poetic cycles. Further study of this issue might look at the ways in which Quevedo had exposure and access to the teachings of Ignatius Loyola, and how familiar Quevedo was with the immense production of spiritual treatises and death manuals Jesuits were writing in seventeenth-century Spain.

\section{Scott Hendrickson}

Loyola University Chicago

dhendrickson@luc.edu

DOI 10.1163/22141332-00502005-03 